\title{
Interview with Richard J. Bernstein
}

Roberto Frega, Giovanni Maddalena and Richard J. Bernstein

\section{(2) OpenEdition}

\section{Journals}

Electronic version

URL: http://journals.openedition.org/ejpap/517

DOI: 10.4000/ejpap.517

ISSN: 2036-4091

\section{Publisher}

Associazione Pragma

\section{Electronic reference}

Roberto Frega, Giovanni Maddalena and Richard J. Bernstein, «Interview with Richard J. Bernstein », European Journal of Pragmatism and American Philosophy [Online], VI-1 | 2014, Online since 08 July 2014, connection on 15 September 2020. URL : http://journals.openedition.org/ejpap/517

This text was automatically generated on 15 September 2020

Author retains copyright and grants the European Journal of Pragmatism and American Philosophy right of first publication with the work simultaneously licensed under a Creative Commons Attribution-

NonCommercial-NoDerivatives 4.0 International License. 


\title{
Interview with Richard J. Bernstein
}

\author{
Roberto Frega, Giovanni Maddalena and Richard J. Bernstein
}

Roberto FREGA \& Giovanni MADDELENA - Can you recollect what the situation was concerning the study of pragmatism when you were in college?

Richard J. BERNSTEIN - I was an undergraduate at the University of Chicago from 1949 to 1951. At the time the "Hutchins College" was an unusual institution. The entire curriculum was fixed and it was organized around reading many of the great books of the Western tradition. From the time I arrived, I was reading Plato, Aristotle, Galileo, Darwin, Herodotus, Thucydides and many other great books. In the undergraduate college there was a negative attitude toward pragmatism. I don't recall ever reading any of the classical pragmatic thinkers. Undergraduate education in the United States is very different from European education. I had a general liberal education - not a specialized philosophical one.

R. F. \& G. M. - What was the University of Chicago like when you were a student there in 1949-51?

Richard J. BERNSTEIN - I was an undergraduate and I had no contact with the graduate philosophy department. But if you consider the careers of those who were students at Chicago, it is an extraordinary group. For example, Susan Sontag, Richard Rorty, George Steiner, Philip Roth - and even Mike Nichols were at Chicago. The faculty too was very distinguished. It was an exciting intellectual and creative environment. The University of Chicago was one of the most exciting intellectual institutions at the time when I was an undergraduate.

\section{R. F. \& G. M. - What was your first encounter with pragmatism?}

Richard J. BERNSTEIN - The first encounter that I had with pragmatism was when I went to study at Columbia University. I enrolled in a course with Justus Buchler. This is the first time that I read the writings of Peirce. But I wasn't interested in pragmatism at the time. I started my graduate studies at Yale in 1953. John E. Smith (who was then a young assistant professor) organized a small reading group dealing with John Dewey's Experience and Nature. This was a revelation for me. I discovered that Dewey was a far more interesting thinker than I had been led to believe. At the time there was a prevailing prejudice that pragmatism was little more than a fuzzy 
anticipation of logical positivism. I decided to write my dissertation on "John Dewey's Metaphysics of Experience". One of my earliest publications was an anthology of Dewey's writings that dealt with metaphysical issues, On Experience, Nature and Freedom. This was a time before we had a critical edition of Dewey's works.

Paul Weiss, one of the editors of the Collected Papers of Charles S. Peirce was on the Yale faculty. So there was also great interest in the work of Peirce. My book, Perspectives on Peirce was based on a series of lectures given by members of the Yale faculty.

R. F. \& G. M. - What was studied at other universities? Positivism and early Analytic Philosophy?

Richard J. BERNSTEIN - During the period just after World War II, a quiet but radical revolution in philosophy in America was taking place. There was an enormous influence of the émigré philosophers who came to the United States during the 1930s. Many of them were associated with the Vienna Circle including Hans Reichenbach, Rudolph Carnap, Herbert Feigl, Carl Hempel, Alfred Tarski - and many others sympathetic with logical empiricism. They had a growing influence on graduate philosophy curriculum. In addition, this was also the time of the highpoint of Oxford ordinary language philosophy as well as the work of Wittgenstein and J. L. Austin. Many prestigious graduate departments were reshaping themselves into analytic departments heavily influenced by the linguistic turn. Interest in classical American pragmatism was at an all-time low.

\section{R. F. \& G. M. - Did you expect pragmatism to be different?}

Richard J. BERNSTEIN - Before I read Dewey and Peirce seriously I had assimilated the common prejudice that positivism and logical empiricism were more "sophisticated" forms of pragmatism. But the more I studied classical pragmatism the more I realized that it was very different from logical positivism. My first teaching position was at Yale and I met Wilfrid Sellars when he joined the Yale faculty. I attended many of his seminars. Sellars taught me to respect the best work in analytic philosophy, and I was also struck by how Sellars' philosophic writings were also close in spirit to pragmatism.

\section{R. F. \& G. M. - Did you consider yourself to be a pragmatist at the time?}

Richard J. BERNSTEIN - Frankly, I have never considered myself to be any kind of "ist" although of course I have been greatly influenced by the pragmatic thinkers. I have always been interested in a variety of thinkers both in the Anglo-American and Continental traditions. Because I have written on the pragmatists as well as Wittgenstein, Arendt, Habermas, Heidegger, Gadamer, Derrida, Foucault (and many others), some people think that I set out to build bridges between different traditions. But from the time that I was a graduate student I have thought that there is only good and bad philosophy (and there is plenty of both on both sides of the Atlantic). When I first started working on the pragmatic thinkers, I thought that they were actually ahead of their time. And I think this is evident today. Many of the themes that were fundamental to the classical pragmatic thinkers have become central in philosophy today. 
R. F. \& G. M. - So you are saying that understanding philosophy as a sort of "constellation"1 was not only typical of your work but also typical of Yale philosophy because it was pluralist?

Richard J. BERNSTEIN - I appropriated the idea of a constellation from the work of Adorno and Benjamin. But I do think the pluralist approach to philosophy at Yale had a great influence on me. I remember being as excited and stimulated by Hegel as I was by Wittgenstein. At the time there was a prejudice in many American philosophy departments that the "linguistic turn" completely transformed philosophy and that there was no need to study the history of philosophy. I never shared this prejudice. What made Yale so distinctive at the time was an open pluralist approach to philosophy (although there was a bias against analytic philosophy) and the talent of the graduate students - including Richard Rorty. It was Dick Rorty and his first wife Amelie Rorty (I knew both of them at Chicago) that convinced me to pursue graduate studies at Yale.

\section{R. F. \& G. M. - What attracted you to the classical pragmatic thinkers?}

Richard J. BERNSTEIN - I was originally attracted to Dewey's rich conception of experience and his commitment to radical participatory deliberative democracy. Dewey led me to see the importance of Hegel for understanding pragmatism. Recently Jeffrey Stout has written an excellent and perceptive comprehensive critical review of my work and he labels me a "Hegelian pragmatist." 2 I read Experience and Nature as Dewey's attempt to naturalize Hegel in light of Darwin's approach to evolution. There is an anecdote that I would like to tell about my early interest in Dewey's metaphysics of experience. My first professional philosophical paper that I presented at the American Philosophical Association was based on my dissertation. I criticized Dewey for not reconciling two strands in his work - a more naturalistic and a more phenomenological strand. John Herman Randall was the chair of this session and he had already written about Dewey's metaphysics. I thought he would severely criticize my paper. But he liked my paper (even though we disagreed) and he published it in the Journal of Philosophy. As you may know that paper is still being discussed and criticized by Dewey scholars - right up to the present. "John Dewey's Metaphysics of Experience" (1961) was my first publication in a philosophical journal.

\section{R. F. \& G. M. - Do you still think there is any room for metaphysics in pragmatism?}

Richard J. BERNSTEIN - "Metaphysics" is a term which has had a bad press in some circles. It suggests the possibility of a "transcendent metaphysics" - the study of what is ultimately real. And, of course, there is a great popularity of the expression "post-metaphysical." Clearly all the classical pragmatic thinkers opposed "transcendent metaphysics" and what Dewey called the "quest for certainty." Pragmatists are some of the sharpest critics of traditional metaphysics. But there is another more open generic sense of metaphysics. All philosophers have some sense of what there really is - of what reality is like (even if they don't speak of metaphysics). Dewey intended to identify what he took to be the generic traits of existence and experience. He did not claim finality or some special philosophic knowledge of reality. Nor did he accept a fixed distinction between appearance and reality.

I might also mention that I was editor of the Review of Metaphysics - a journal founded by Paul Weiss. I was appointed as the successor to Weiss. What was distinctive about 
the Review is that it was a genuinely pluralistic journal. We published translations of Heidegger as well as Quine, Sellars and Rorty and Leo Strauss.

\section{R. F. \& G. M. - How long were you editor of the Review of Metaphysics?}

Richard J. BERNSTEIN - When Paul Weiss appointed me editor he told me to edit it as long as I was learning something and enjoying the experience. The Review functioned in a very unique way. The editor read all the submitted manuscripts and made all the decisions about publication. And the editor also wrote a personal letter about each manuscript submitted. I was assistant editor from 1961-1964 and editor from 1964 until 1971. I was reading almost 400 manuscripts a year. I decided to give up the editorship in 1971 because I followed Paul's advice. I was not interested simply in the prestige and power of being the editor of a philosophical journal that had one of the largest circulations. I enjoyed being editor and learned a great deal from the experience but I went on to other projects. In 1981 I became a founding editor of Praxis International.

R. F. \& G. M. - If you don't call yourself a pragmatist, what is your place in the pragmatic tradition?

Richard J. BERNSTEIN - I have been inspired by the classical American pragmatic thinkers. But I think that a pragmatic orientation requires openness to other approaches and other traditions. I have tried to practice this openness in my encounters with thinkers in the Anglo-American tradition as well as the Continental tradition. In my book, The Pragmatic Turn (2010) I argued that pragmatic themes have become fundamental in much of philosophy today. Pragmatism is more widely discussed today than at any time in the past.

R. F. \& G. M. - Some people say that there is a canon in American philosophy. And the canon is formed by seven thinkers: Peirce, James, Dewey, Mead, Royce, Whitehead, and Santayana.

Richard J. BERNSTEIN - Although I think all of the above have made interesting philosophical contributions, I strongly object to the idea of a fixed canon. The truth is that from its very origins there have been arguments about who is and who is not a pragmatist. Furthermore, close analysis of the seven philosophers mentioned above shows how radically different they are from each other. There have been arguments about what - if anything - is distinctive about American philosophy. What is mistaken about "canon" thinking is that it leaves out many important figures such as Jane Addams and Alain Locke who have made important contributions to American philosophy. It also leaves out important figure such as Quine, Sellars, Rorty, and Brandom. If we are to be true to what is best in the American tradition, then we should be skeptical about any fixed canon and to be open and sensitive to new developments. Or you might say that the "canon" is always being rewritten in light of new developments.

R. F. \& G. M. - What do you consider to be pragmatic in your philosophy?

Richard J. BERNSTEIN - At different times in my career I have attempted to identify characteristic themes in the pragmatic tradition that I share. For example in the presidential address that I gave to the Eastern Division of the American Philosophical Association, "Pragmatism, Pluralism, and the Healing of Wounds" I listed the following interrelated themes that characterize the pragmatic ethos: antifoundationalism; fallibilism; the nurturing of critical communities of inquirers; 
radical contingency; and pluralism. Different pragmatic thinkers have approached these themes in different ways. I have developed all of these themes in my work. In the prologue to The Pragmatic Turn, I argue that we can detect pragmatic themes in Wittgenstein and Heidegger. I also subscribe to Dewey's idea of radical democracy as a way of life in which all share and all participate.

R. F. \& G. M. - The conviction that seems to be at the heart of your work is the ability to open pragmatic traditions to all kinds of multiple conversations. It is still an open question whether the twentieth century can be characterized as The Pragmatic Century - as you claim. For some thinkers there is a dialectical tension between pragmatist and the pragmatic. Do you think there is a distinctive contribution of pragmatists to the pragmatic tradition?

Richard J. BERNSTEIN - If I understand the gist of your question, I want answer that the classical pragmatists have something to contribute to a larger pragmatic tradition. The classical pragmatists were all robust non-reductive naturalists. They were all influenced by Darwin. We also need to realize that the philosophic writings of Peirce, James, Dewey and Mead include far more than their focus on specific pragmatic theses. I think it is an accident of history that we use the label "pragmatic" to identify these thinkers. We should recall that Peirce did not even use the expression "pragmatism" until James published his famous essay "Philosophical Conceptions and Practical Results" in 1898. And Dewey thought of himself primarily as advocating an experimental philosophy. I have suggested that "pragmatism" is like an accordion expression. Sometimes it is used in a very broad sense to label these thinkers. Other times it is used more narrowly to focus on their theories of meaning and truth. The classical pragmatic thinkers did not see any fixed distinction between philosophy and science. Furthermore, they did not see any sharp ontological breaks in the world. Now if we consider the European phenomenological tradition going back to Husserl there is a critique of naturalism. But the naturalism that Husserl criticizes is a reductive naturalism. I consider my own work in the pragmatic tradition of robust non-reductive naturalism. I am also skeptical of those who want to draw a sharp distinction between science and philosophy. At different times in history there have been important differences between science and philosophy, but the boundary is fluid and changing. Philosophy should always be open to what it can learn from new developments in all the sciences - both the natural and the social sciences. Although I have my disagreements with Robert Brandom I am sympathetic with his attempt to show the pragmatic motifs in Hegel, Heidegger and Wittgenstein. I don't think there is a set of fixed theses that establishes the essential core of pragmatism. The pragmatic tradition is a dynamic one that includes a variety of different voices. Philosophers who identify themselves as pragmatists have always argued about what constitutes the meaning of pragmatism. And these debates are still very much alive.

R. F. \& G. M. - Do you think that pragmatism (even Peirce) is more Hegelian than Kantian?

Richard J. BERNSTEIN - We need to distinguish different strands in the pragmatic tradition. There is a strong Kantian strand. We see this in Peirce, Sellars, and Putnam. And recently Habermas has characterized himself as a "Kantian Pragmatist." Dewey, of course, was much more influenced by Hegel. And he shares Hegel's critique of Kant. But even Kantian pragmatists reject many of the fundamental distinctions that we find in Kant such as the distinction between phenomena and noumena. They also reject Kant's table of categories as fixed and permanent. They basically accept many of Hegel's criticisms of Kant. And like Hegel they emphasize the interaction of history 
and philosophy. My own sympathies are with a Hegelian approach to pragmatism. But we should not forget that Hegel himself begins with appropriating Kantian themes - and then moving beyond them.

R. F. \& G. M. - Many themes in your work are connected with the Jewish tradition. What has been the impact of this tradition on your work?

Richard J. BERNSTEIN - I find it difficult to give a clear answer to this question. I am a Jew and I am proud of it. I grew up in a second generation Jewish immigrant family in New York. I have never felt any conflict between being a Jew and an American (and a philosopher). At a certain point in my career I became fascinated with twentieth century Jewish intellectuals. I wanted to understand how their Jewishness affected their intellectual work. I wrote two books dealing with this topic: Hannah Arendt and the Jewish Question (1996) and Freud and the Legacy of Moses (1998). Both Arendt and Freud were secular Jews. I argue that Jewish questions are central to their work. Although I am interested in the Jewish tradition, I am not a scholar of the Jewish tradition. Furthermore, I am very skeptical and critical of the recent fascination with political theology.

R. F. \& G. M. - You say that you are skeptical about political theology. Are you skeptical about religion in general?

Richard J. BERNSTEIN - No. I do not consider myself to be a militant atheist. I am really more agnostic. All of the classical pragmatists appreciated the role of religion in human life. They were anti-authoritarian and anti-dogmatic not anti-religious. We need to take account of the significant role of religions in the contemporary world. I am however distressed about the recent influence of Carl Schmitt's conception of political theology. I strongly object to those who think that all politics does or must presuppose religion or theology. ${ }^{4}$ of course the problem of world religions and the way they influence politics has become a global issue today.

R. F. \& G. M. - Concerning democracy, what is your position about the debates concerning communitarianism and liberalism?

Richard J. BERNSTEIN - I think that the dichotomy between liberalism and communitarianism is a misleading one. My position is close to Dewey who was a radical democrat, a radical liberal and who also appreciated the significance of public communal debate for a creative democracy. Much of contemporary liberalism has been a rights obsessed liberalism. Dewey was well aware that liberalism, which once was a radical doctrine, has become rigidified and frequently used as a defense of the status quo. And Dewey also thought that a "business mentality" was undermining democracy. From his earliest work he attacked (in a Hegelian manner) the "liberal" idea of the isolated individual. Individuality is an achievement and the quality of individuality is itself dependent on the type of communities in which we live. Dewey's vision of what democracy can become overcomes the division between liberalism and communitarianism. And I agree with him.

R. F. \& G. M. - What has been your relationship with other contemporary philosophers who identify with the pragmatic tradition?

Richard J. BERNSTEIN - I have been in active discussion with many other pragmatic thinkers including Richard Rorty, Hilary Putnam, Robert Brandom, and Jürgen Habermas. I discuss all of these thinkers in The Pragmatic Turn - and I have had personal friendships with them. I knew Dick Rorty for more than fifty years. Habermas has been a close friend since the early 1970s. We have had intellectual 
differences and public debates but we share much in common. I believe that philosophic discussion is based upon and cultivates deep friendship.

R. F. \& G. M. - What do you think has been the most significant debates that you have had with other philosophers?

Richard J. BERNSTEIN - Rorty and Habermas have been close intellectual and personal friends. Concerning Rorty we have had many public exchanges on a variety of issues. I have sometimes said that there are two Rortys - the reasonable Rorty with whom I mostly agree - and the outrageous Rorty who loves to provoke. My deepest disagreement with Rorty concerns our different views of democracy. Rorty emphases "ironic liberalism" and I favor a more active participatory deliberative democracy. Concerning Habermas, I detect a pragmatic and a more transcendental strain in his thinking. We have debated these issues for forty years and I have sought to "detranscendentalize" him. Habermas is a bit too Kantian for my taste and I have sought to press Hegelian and pragmatic critiques against him.

R. F. \& G. M. - What do you think about the current state of philosophy in America and the future of philosophy in America? Isn't there still a strong predominance of analytic philosophy?

Richard J. BERNSTEIN - Frankly I find the general situation of philosophy in America today a bit depressing. Much of this is due to the excessive professionalization of academic life. Rorty was right when he suggested that academic philosophy is becoming more and more marginal to human life - and even marginal to the humanistic disciplines. Even among analytic philosophers I see a sharp difference between the initial stages of this movement and the way it is practiced today. Whatever one's critical evaluation of Carnap, Quine, Sellars, and Davidson one must acknowledge that they were bold thinkers. And their views have important ramifications for a wide range of philosophic issues. But much of today's philosophic writing is so specialized that it is difficult to see its significance or relevance. There are of course some notable exceptions. Even among pragmatic thinkers there are now divisions. We should remember that for all the differences among Peirce, James, and Dewey they were engaged in conversation with each other.

R. F. \& G. M. - Do you think this situation has resulted from the specialization in analytic philosophy?

Richard J. BERNSTEIN - I think this part of a larger problem - the professional specialization of academic life. And it seems to be getting worse and worse. When I was a graduate student, one had a sense of outstanding thinkers who would have a significant impact on philosophy - regardless of one's orientation. I was a graduate student when Wittgenstein's Philosophical Investigations was published and when J. L. Austin was widely discussed. In Germany, Heidegger and Gadamer were influential. And one knew about the importance of Habermas even when he was a young man. In France there was Ricœur, Derrida, and Foucault. Perhaps I am a bit jaded but I do not see many philosophic thinkers of their caliber today. I am not completely pessimistic. For I see many younger philosophers and pragmatic thinkers who are not happy with the current situation. I don't want to predict the future, but I hope that the bold speculative imaginative spirit that was characteristic of the early pragmatic thinkers will reassert itself. 
R. F. \& G. M. - You mentioned "conversation" and "dialogue" as a distinctive mark of your philosophy and your epoch. I wonder if you think this dialogue and conversation is still possible on the contemporary philosophic scene.

Richard J. BERNSTEIN - You may recall the last sentence of Rorty's Philosophy and the Mirror of Nature: "The only point on which I insist is that philosophers' moral concern should be with continuing the conversation of the West, rather than with insisting upon a place for the traditional problems of modern philosophy within that conversation." I basically agree with Rorty although I don't think the conversation should be limited to the "West." Intellectually we are now living in a global world. During my lifetime, I have had the good fortune to be in conversation with many philosophic friends including Hannah Arendt, Alasdair MacIntyre, Charles Taylor, Richard Rorty, Jacques Derrida, and Jürgen Habermas. We have had our disagreements but the conversations have always been civil and fruitful. And I see many younger philosophers yearning to engage in such conversations. I deeply believe in engaged pluralism. My hope is that this spirit of engaged agonistic friendly dialogue will mark the future of philosophy.

\section{NOTES}

1. The New Constellation: The Ethical-Political Horizon of Modernity/Postmodernity (1991).

2. Jeffrey Stout “The Spirit of Pragmatism: Bernstein's Variations on Hegelian Themes," Graduate Faculty Philosophy Journal 33/1 (2012).

3. "Pragmatism, Pluralism, and the Healing of Wounds," in The New Constellation (1991).

4. For my critique of Carl Schmitt, see my Violence Thinking without Banisters (2013). For my critique of political theology see "Is Politics 'Practicable' without Religion?," in Social Research 80/1 (2013). 